\title{
Dissociation of Rhodococcus rhodochrous Population after the Whole Cells Immobilization
}

\author{
Inna RASTIMESINA ${ }^{1 *}$, Olga POSTOLACHI ${ }^{1}$, Valentina JOSAN ${ }^{1}$
}

\author{
${ }^{1}$ Institute of Microbiology and Biotechnology, MECR, Academiei 1, Chisinau, MD-2028, Republic of Moldova \\ *Corresponding author: I. Rastimesina e-mail: rastimesina@gmail.com
}

RESEARCH ARTICLE

\begin{abstract}
Six agricultural organic wastes and three inorganic matrices were selected for rhodococci whole cells immobilization. The degree of immobilization of rhodococci cells varied from $6.20 \%$ to $34.30 \%$ on organic matrices. A high level of Rhodococcus rhodochrous CNMN-Ac-05 cells immobilization was demonstrated on inorganic matrices, it was from $69.25 \%$ to $97.30 \%$. After the contact with support the strain dissociated, forming in addition to original S type, rough (R) and altercolour smooth (S) types. Immobilization of rhodococci cells on organic supports led to the appearance of phenotypic heterogeneity from $0.34 \%$ to $3.26 \%$. On inorganic matrices the variability of rhodococci was $0.88-1.05 \%$.
\end{abstract}

Keywords: immobilization; organic/inorganic matrix; dissociation.

Received: 16 October 2020 Accepted: 25 January 2021 Published: 15 May 2021

DOI:

10.15835/buasvmcn-agr:2020.0043

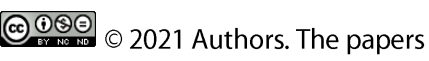
published in this journal are licensed under the Creative Commons Attribution-NonCommercialNoDerivatives 4.0 International License
}

\section{INTRODUCTION}

Actinobacteria from the genus Rhodococcus synthesize a wide range of enzymes, such as dehydrogenases, peroxidases, oxygenases (Kim et al., 2018), that make these bacteria able to assimilate a wide range of organic compounds, among which are phenols, aromatic acids, esters, halogenated hydrocarbons, heterocyclic compounds, and synthetic polymers (Krivoruchko et al., 2019). Representatives of the genus Rhodococcus are used for detoxification of dangerous chemicals, for example polycyclic aromatic hydrocarbons (PAHs), polychlorinated biphenyls (PCBs), in bioremediation of soil contaminated with pesticides (Bell et al., 2018; Kitova et al., 2002; Kuyukina and Ivshina, 2010; Solyanikova et al., 2018; Krivoruchko et al., 2019). However, there are some limitations to use free cells in bioremediation, which includes substrate inhibition, low biodegradation rate, and cells separation from the products after catalysis (Willaert, 2006). Numerous biotechnological processes, such as alcoholic and malolactic fermentation of wine (Kourkoutas, 2010; Moreno-García et al., 2018), treatment of toxic pollutants in industrial wastewater (Martins et al., 2013), bioremediation of contaminated soil (Ivshina et al., 2013; Cubitto and Gentili, 2015; Dzionek et al., 2016) are advantaged by immobilization techniques. In the course of long-term growth of microorganisms on toxic substances, the dissociation of microbial population, due to process of variability, occurred (Kolomytseva et al., 2005; Stancu, 2015; Ackermann, 2015). Numerous studies on the organization of microbial colonies provide evidence of the morphological and physiological heterogeneity of cell composition (Voloshin, 2005; Silva et al., 2012; Hewitt et al., 2016; Van Boxtel et al., 2017; Calabrese et al., 2019). The immobilized 
cell technology can be applied for long-term stabilization remediating microorganisms (Kuyukina and Ivshina, 2010; Krivoruchko et al., 2019).

This paper presents the results of estimation of phenotypic heterogeneity of the strain Rhodococcus rhodochrous CNMN-Ac-05, after the immobilization of whole cells on organic and inorganic matrices.

\section{MATERIALS AND METHODS}

This strain of Rhodococcus rhodochrous CNMN-Ac- 05 was deposited in the National Collection of Non-Pathogenic Microorganisms of the Republic of Moldova. The strain $R$. rhodochrous was grown under continuous aeration conditions on a stirrer at $180-200 \mathrm{rpm}$ at $28^{\circ} \mathrm{C}$, for 48 hours, on Tryptic soy (TS) broth medium (Sigma-Aldrich). $R$. rhodochrous cell mass was separated by centrifugation for 30 minutes at $5000 \mathrm{rpm}$ and washed twice with $\mathrm{NaCl}$ solution $(0.8 \%)$.

The R. rhodochrous biomass was determined on the spectrophotometer by the optical density OD 540 of rhodococci cell suspensions, with subsequent recalculation of the dry mass of the cells according to the calibration curve. The dry biomass of $R$. rhodochrous was determined by gravimetric method, by drying at $105^{\circ} \mathrm{C}$.

Six organic and three inorganic matrices were selected for rhodococci whole cells immobilization. There were agricultural organic wastes: sunflower husk, pumpkin husk, pistachio shells, common walnut shells, peanut shells, and hazelnuts shells. Inorganic support materials were: bentonite, diatomite, and kieselguhr. Organic substrates were crushed, sifted through sieve No. 0.5 and washed until clear water was obtained. All materials were washed with distilled water in three repeats and passed through deionized water the same in three repeats. The supports were dried in an oven for $2-3$ hours at $80-90^{\circ} \mathrm{C}$ to set up the constant weight. A $1.0 \mathrm{~g}$ sample was placed in a $250 \mathrm{ml}$ Erlenmeyer flask, then the supports were sterilized at $1 \mathrm{~atm}$ for 15 minutes.

In order to immobilize rhodococci cells, Knapp buffer was used with the following composition g/L: $\mathrm{K}_{2} \mathrm{HPO}_{4}-$ 1.0; $\mathrm{KH}_{2} \mathrm{PO}_{4}-1.0 ; \mathrm{MgSO}_{4} \times 7 \mathrm{H}_{2} \mathrm{O}-0.04 ; \mathrm{FeCl}_{3} \times 6 \mathrm{H}_{2} \mathrm{O}-0.004$, $\mathrm{pH}-6.7$. $R$. rhodochrous whole cells, $150 \mathrm{mg}$, and 50 $\mathrm{ml}$ of Knapp buffer were added to a $250 \mathrm{ml}$ Erlenmeyer flask with $1 \mathrm{~g}$ of sterile support. In other flask, only Knapp buffer was added, without the addition of cells. Flasks were placed under continuous aeration conditions on shaking 180-200 rpm for 20 minutes, $t=24^{\circ} \mathrm{C}$, then placed in the refrigerator for $16-20$ hours (Kitova et al., 2002). The content of the flasks was filtered through a capron filter. The support on the filter was washed three times with Knapp buffer, $50 \mathrm{ml}$ for each wash. The filtrate was poured into a volumetric flask, adjusted to $250 \mathrm{ml}$ with Knapp buffer.

The amount of immobilized cells was spectrophotometrically estimated, by measuring the OD 540 optical density of the liquid medium before and after immobilization, and by quantifying the number of viable bacterial cells (colony forming units, CFU) inoculated on TS agar medium before and after immobilization.

The morphological features of the rhodococci colonies were described according to method (Papacostea, 1976) using a magnifying glass (8-fold magnification).

Statistical analysis was performed using MS Excel. All results were expressed as mean of three individual replicates $\pm \mathrm{CI}$ (confidence intervals). All differences were considered significant at $P<0.05$.

\section{RESULTS AND DISCUSSIONS}

Agricultural wastes have become alternative support materials for cell immobilization because they are environmentally friendly, locally available and cheaper than synthetic polymers. Researchers indicated successful use of various agricultural residues to immobilize microbial cells for bioremediation purpose (Cubitto and Gentili, 2015; Dzionek et al., 2016).

On the organic matrices the degree of immobilization of rhodococci cells varied from $6.20 \%$ (sunflower seed husk) to $34.30 \%$ (peanut shell) (Figure 1).

Silicon-containing inorganic carriers were chosen as supporting matrix due to their characteristics, such as insoluble in water, high ion exchange ability, inexpensive, wide particle surface, easily activated, rigid, stable and non-toxic (Yandri et al., 2018).

On inorganic supports the degree of immobilization was $69.25 \%$ - bentonite, $74.76 \%$ - diatomite, and $97.30 \%$ on kieselguhr (Figure 2).

R. rhodochrous cells, grown on TS agar medium, formed colonies of a similar smooth shape, that had a homogeneous pink colour and slightly glistering surface (Goodfellow and Alderson, 1977; Goodfellow and Maldonado, 2006). This features of colonies correspond to basic morphological type S. After the contact with support, in the process of immobilization, the strain dissociated, forming original smooth (S), rough (R) and altercolour smooth (Sa) types (Figure 3).

Immobilization of rhodococci cells on organic supports led to the appearance of phenotypic heterogeneity, the frequency of dissociation was from $0.34 \%$ (hazelnut shell) to $3.26 \%$ (pistachio shell) (Figure 4). 
The cells contact with the husks of pumpkin and sunflower seeds was reflected in the appearance of $\mathrm{R}$ type, the variability was $1.38 \%$ and $0.83 \%$, respectively (Figure 5). After the Rhodococcus cells were immobilized on the shells of pistachios, peanuts, walnuts and hazelnuts, $\mathrm{R}$ and altercolour Sa colony types appeared.

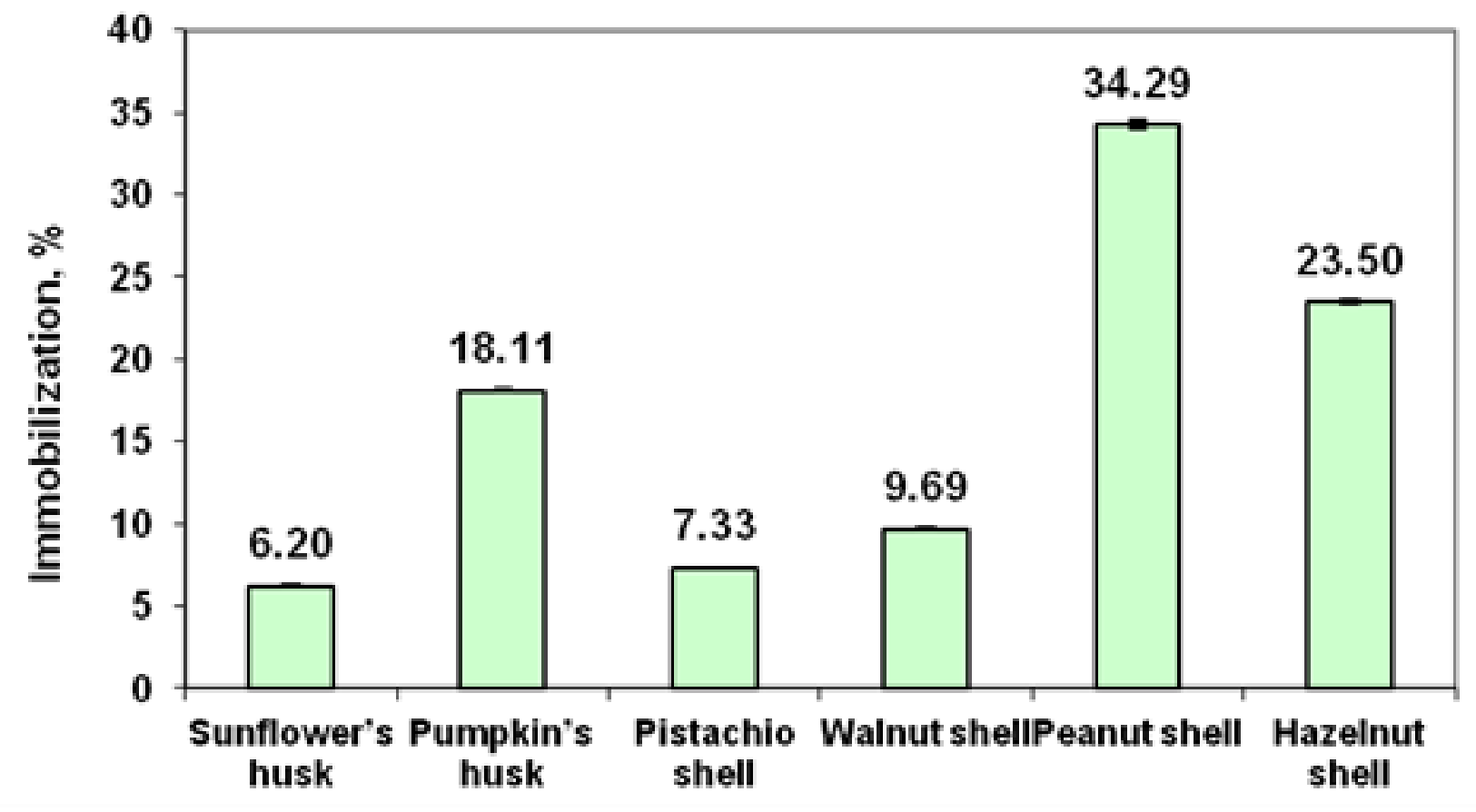

Figure 1. The immobilization efficiency of the organic matrices after the adsorption of $R$. rhodochrous CNMN-Ac-05 cells

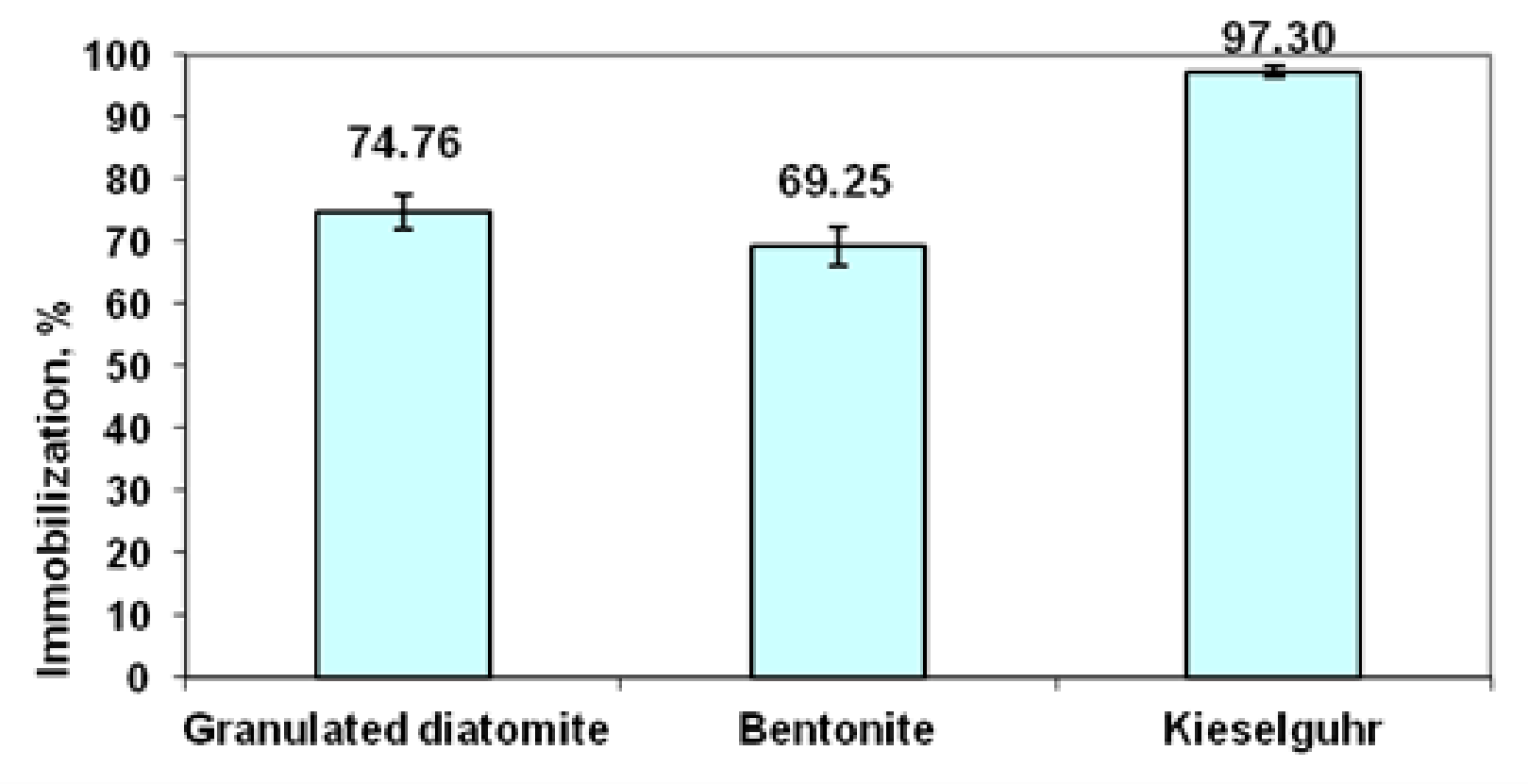

Figure 2. The immobilization efficiency of the inorganic matrices after the adsorption of $R$. rhodochrous CNMN-Ac-05 cells

After the contact of R. rhodochrous cells with silicon-containing inorganic carriers, the frequency of dissociation was $0.88 \%$ (bentonite), $0.94 \%$ (diatomite), and $1.05 \%$ (kieselguhr) (Figure 6).

The appearance of $\mathrm{R}$ type was noted, and, in the case of diatomite and kieselguhr, the strain also formed white altercolour Sa type of colonies (Figure 7). 


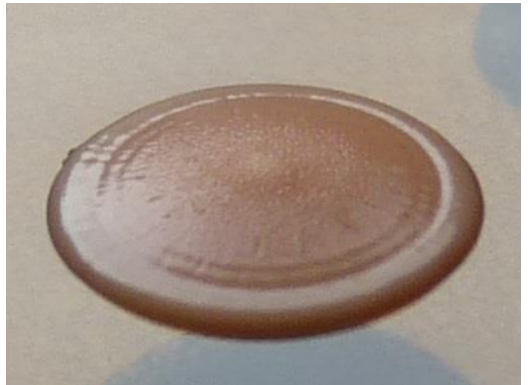

(a)

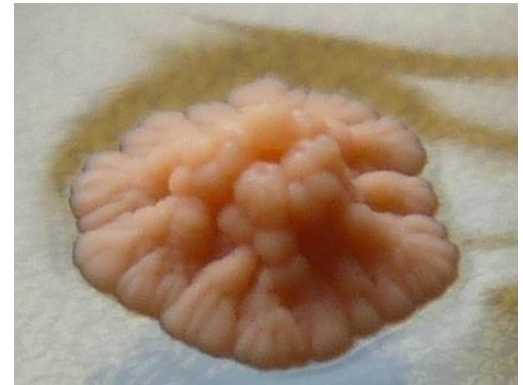

(b)

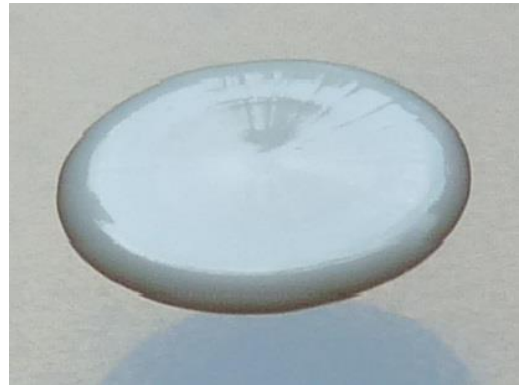

(c)

Figure 3. The types of colonies formed by the strain $R$. rhodochrous CNMN-Ac-05 after the contact with matrices: (a) - type S; (b) type R; (c) type Sa).

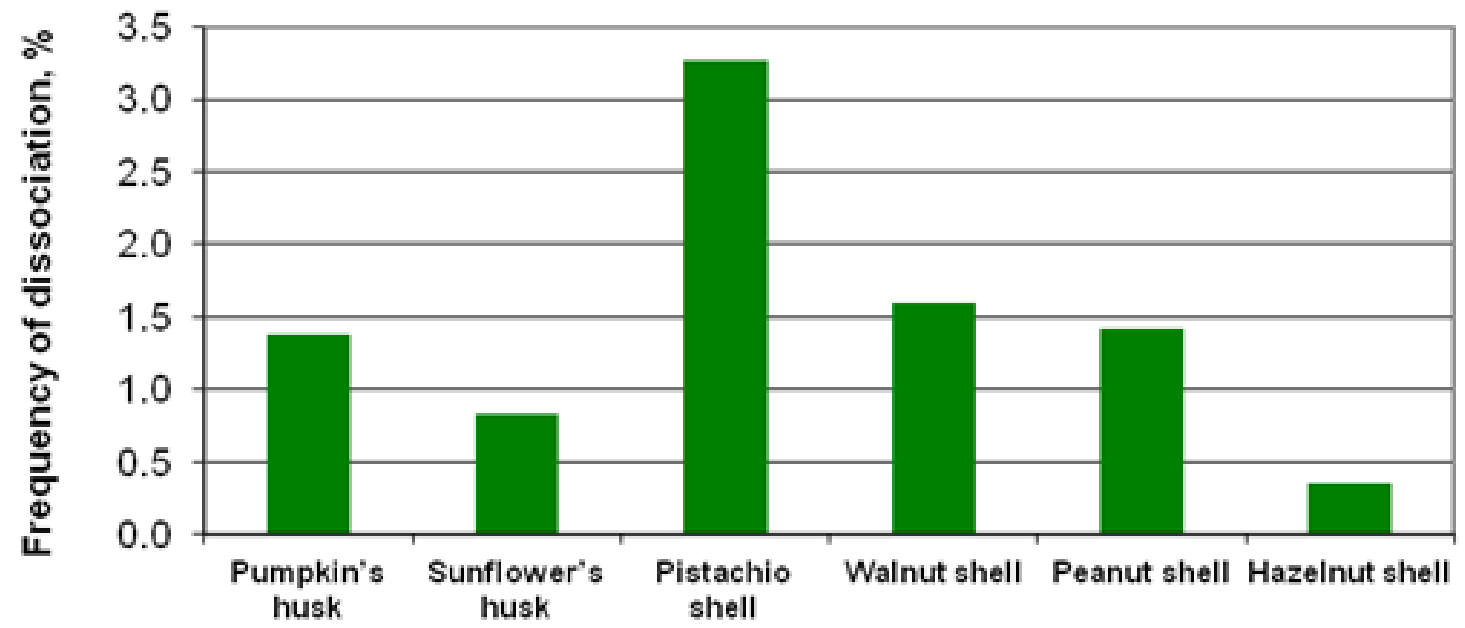

Figure 4. The dissociation of the strain $R$. rhodochrous CNMN-Ac-05 after the contact with organic matrices

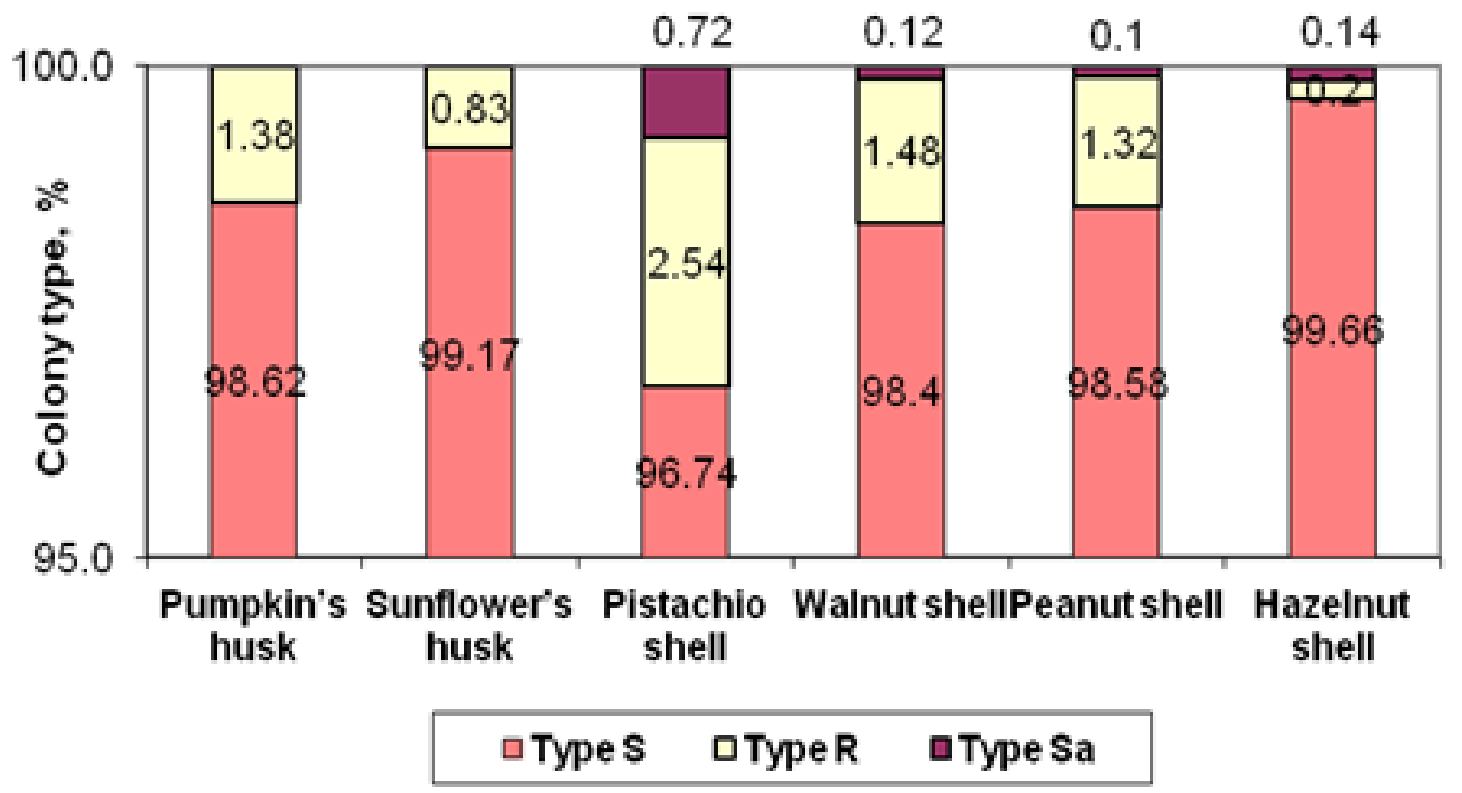

Figure 5. The natural variability of the strain $R$. rhodochrous CNMN-Ac-05 after the contact with organic matrices 


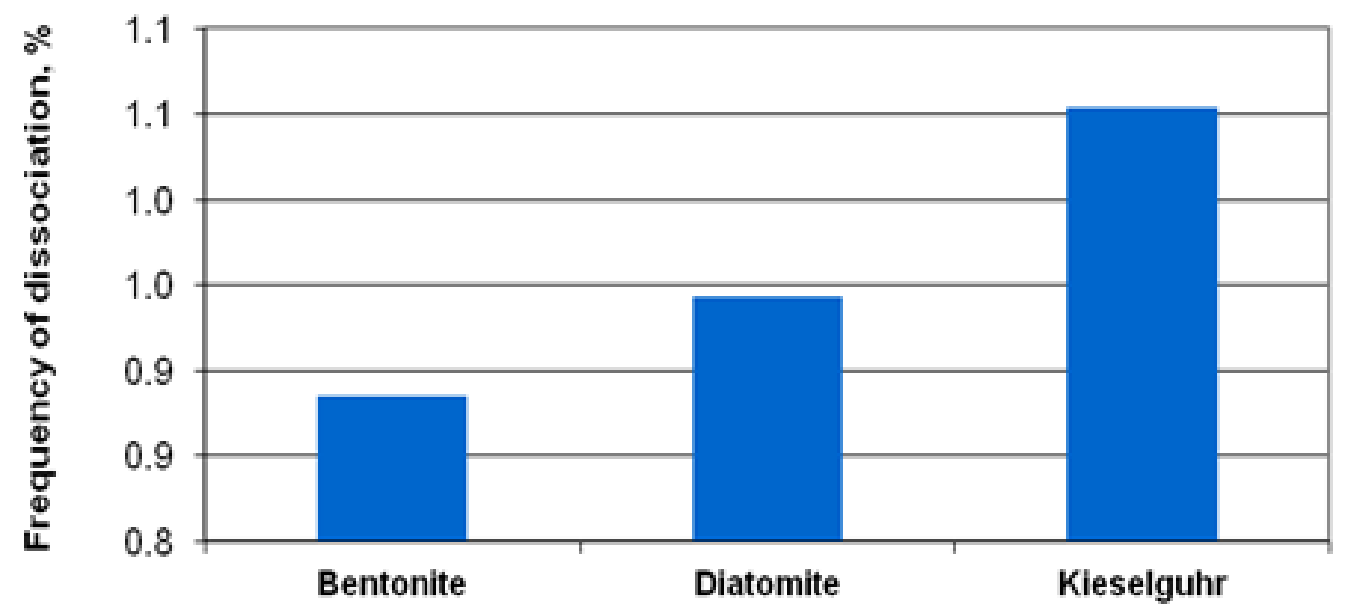

Figure 6. The dissociation of the strain $R$. rhodochrous CNMN-Ac-05 after the contact with inorganic matrices

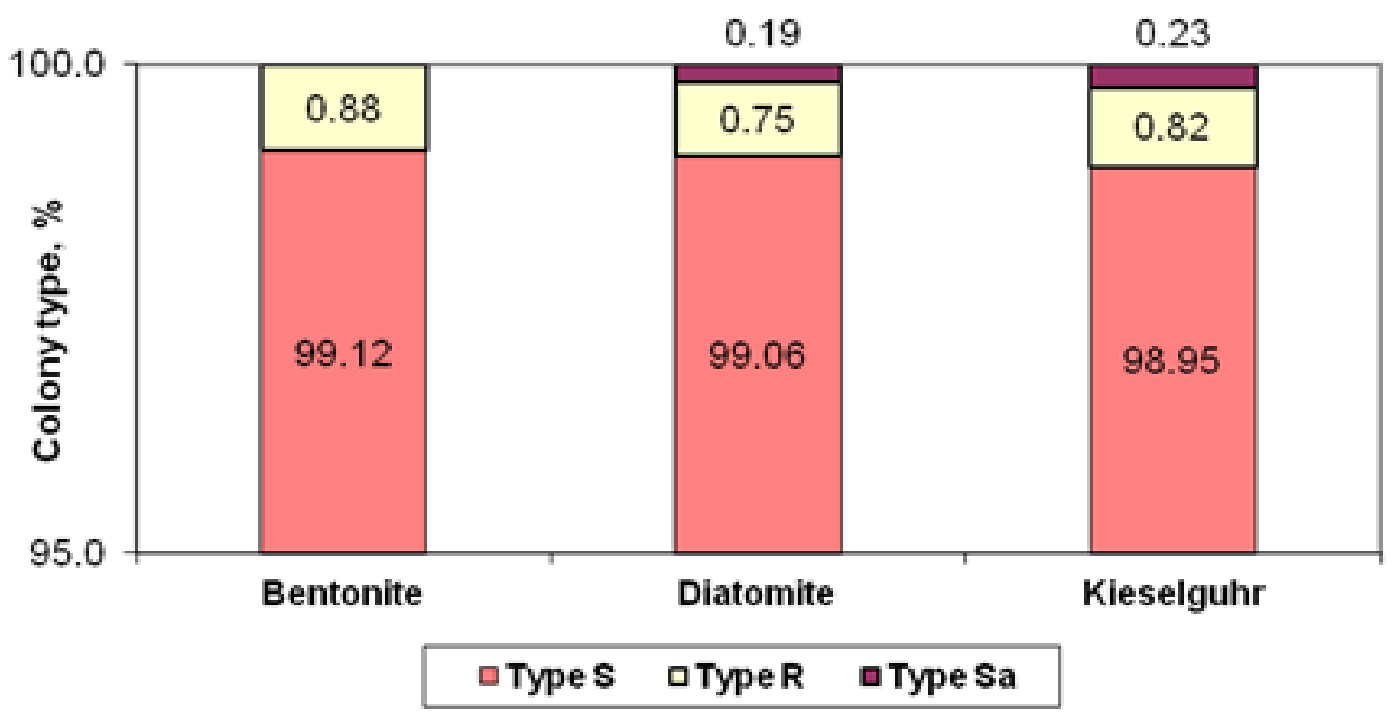

Figure 7. The natural variability of the strain $R$. rhodochrous CNMN-Ac-05 after the contact with inorganic matrices

\section{CONCLUSIONS}

A high level of R. rhodochrous cells immobilization was obtained on inorganic matrices. Kieselguhr demonstrated the highest adsorbent quality, providing the immobilization efficiency of $97.30 \%$.

Immobilization of rhodococci cells on organic and inorganic matrices led to the appearance of phenotypic heterogeneity, the frequency of dissociation depended on the support material.

\section{Author Contributions:}

All authors contributed equally to the work.

Funding Source: This work has been realized with the support of Moldova-Belarus Bilateral Project 19.80013.51.07.09A/BL.

\section{Conflicts of Interest}

The authors declare that they do not have any conflict of interest. 


\section{REFERENCES}

1. Ackermann M. A functional perspective on phenotypic heterogeneity in microorganisms. Nature Reviews Microbiology 2015; 13: 497-508.

2. Bell KS, Philp JC, Aw DWJ, Christofi N. The genus Rhodococcus. Journal of Applied Microbiology 1998; 85: 195210.

3. Calabrese F, Voloshynovska I, Musat F, Thullner M, Schlömann M, Richnow HH, Lambrecht J, Müller S, Wick LY, Musat N, Stryhanyuk H. Quantitation and comparison of phenotypic heterogeneity among single cells of monoclonal microbial populations. Front Microbiol. 2019; Doi:10.3389/fmicb.2019.02814

4. Cubitto MA, Gentili AR. Bioremediation of crude oil - Contaminated soil by immobilized bacteria on an agroindustrial waste - Sunflower seed husks. Bioremediation Journal 2015; 19: 277-286.

5. Dzionek A, Wojcieszyńska D, Guzik U. Natural carriers in bioremediation: A review. Electronic Journal of Biotechnology 2016; 23: 28-36.

6. Goodfellow M, Alderson G. The actinomycete-genus Rhodococcus: A home for the 'rhodochrous' complex. Journal of General Microbiology 1977; 100: 99-122.

7. Goodfellow M, Maldonado LA. The families Dietziaceae, Gordoniaceae, Nocardiaceae and Tsukamurellaceae. In: Dworkin M, Falkow S, Rosenberg E, Schleifer KH, Stackebrandt E, editors. The Prokaryotes. A handbook on the biology of bacteria. 3rd ed. New York: Springer; 2006. p. 843-888.

8. Ivshina IB, Kuyukina MS, Krivoruchko AV, Plekhov OA, Naimark OB, Podorozhko EA, Lozinsky VI. Biosurfactantenhanced immobilization of hydrocarbon-oxidizing Rhodococcus ruber on sawdust. Appl Microbiol Biotechnol. 2013; 97: 5315-5327.

9. Hewitt SK, Foster DS, Dyer PS, Avery SV Phenotypic heterogeneity in fungi: Importance and methodology. Fungal Biology Reviews 2016; 30: 176-184.

10. Kim D, Choi KY, Yoo M, Zylstra GJ, Kim E. Biotechnological potential of Rhodococcus biodegradative pathways. Journal of Microbiology and Biotechnology 2018; 28(7): 1037-1051.

11. Kitova AE, Kuvichkina TN, Il'yasov PV, Arinbasarova AIu, Reshetilov AN. A biosensor of the reactor type based on Rhodococcus erythropolis HL PM-1 cells for detecting 2-4-dinitrophenol. Applied Biochemistry and Microbiology, 2002; 38(5): 585-590.

12. Kolomytseva MP, Solyanikova IP, Golovlev EL, Golovleva LA. Heterogeneity of Rhodococcus opacus 1CP as a response to stress induced by chlorophenols. Applied Biochemistry and Microbiology 2005; 41(5): 474-479.

13. Krivoruchko A, Kuyukina M, Ivshina I, Advanced Rhodococcus biocatalysts for environmental biotechnologies. Catalysts 2019; Doi:10.3390/catal9030236.

14. Kuyukina MS, Ivshina IB Application of Rhodococcus in bioremediation of contaminated environments. In: Alvarez HM, editor. Biology of Rhodococcus, Microbiology Monographs. Volume 16. Springer-Verlag Berlin Heidelberg; 2010. p. 231-252.

15. Martins SCS, Martins CM, Fiúza LMCG, Santaella ST. Immobilization of microbial cells: A promising tool for treatment of toxic pollutants in industrial wastewater. African Journal of Biotechnology 2013; 12(28): 44124418.

16. Moreno-García J, García-Martínez T, Mauricio JC, Moreno J. Yeast immobilization systems for alcoholic wine fermentations: actual trends and future perspectives. Frontiers in Microbiology 2018; Doi:10.3389/fmicb.2018.00241.

17. Papacostea P. Soil Biology. Bucharest: Editura Științifică și Enciclopedică; 1976. p. 153-158.

18. Silva P, Santos ACB, Sato DN, Silva JO, Medeiros MIC, Carneiro AMM, Leite SRA, Leite CQF, Phenotypic and genotypic characterization of Rhodococcus equi isolated from sputum. The Brazilian Journal of Infectious Diseases 2012; 16(5): 409-415.

19. Solyanikova I, Suzina N, Golovleva L. The role of non-spore-forming actinobacteria in cleaning up sites contaminated by persistent pollutants and the ability of these microorganisms to survive under unfavourable conditions. Microbiology Australia 2018; 39(3): 141-144.

20. Stancu MM. Response of Rhodococcus erythropolis strain IBBPo1 to toxic organic solvents. Brazilian Journal of Microbiology 2015; 46(4): 1009-1018.

21. Van Boxtel C, Van Heerden JH, Nordholt N, Schmidt P, Bruggeman FJ, Taking chances and making mistakes: nongenetic phenotypic heterogeneity and its consequences for surviving in dynamic environments. J R Soc Interface. 2017; Doi:10.1098/rsif.2017.0141.

22. Voloshin SA, Shleeva MO, Syroeshkin AV, Kaprelyants AS The role of intercellular contacts in the initiation of growth and in the development of a transiently nonculturable state by cultures of Rhodococcus rhodochrous grown in poor media. Microbiology 2005; 74(4): 420-427.

23. Willaert RG. Cell immobilization and its applications in biotechnology: current trends and future prospects. In: El-Mansi EMT, Bryce CFA, Demain AL, Allman AR, editors. Fermentation Microbiology and Biotechnology. Third edition. CRC Press; 2006. p. 313-367. 
24. Yandri T, Suhartati S, Yuwono D, Qudus HI, Tiarsa ER, Hadi S. Immobilization of $\alpha$-amylase from Bacillus subtilis ITBCCB148 using Bentonit. Asian Journal of Microbiology, Biotechnology and Environmental Sciences 2018; 20(2): 487-492.

25. Zur J, Wojcieszynska D, Guzik U. Metabolic responses of bacterial cells to immobilization. Molecules 2016; 21(7): 958-972. 